\title{
Water Quality Modeling for Integrated Management of Urban Stream Networks
}

\author{
Yoon Jeong Yeon, Dong Hee Kim, and Jung Lyul Lee
}

\begin{abstract}
This study presents a water quality Management program for Urban River Networks (WAQUMURIN). The model analyzes a variety of water quality problems in urban stream networks linked by ponds, lakes, and reservoirs, which are subdivided into unit reach cells. A mass balance is performed in each cell for the nonconservative contaminants loaded from point and nonpoint sources on land. The model was designed by GUI to provide a practical program for management purposes. To test the performance of the model, it was applied to the Han River network in the city of Seoul, Korea, which has eight stream branches. The test was conducted for BOD load and compared with measured data.
\end{abstract}

\section{Index Terms-Cascade model, BOD, GUI, Seoul.}

\section{INTRODUCTION}

Many different types of water quality models are available nowadays; however, it is not easy to select an appropriate model that consistently achieves maximum simplicity with the required degree of accuracy and detail. The decision for which model to use should be made carefully to avoid over complication of the model by eliminating physical, chemical, or biological relationships that do not significantly affect the simulation objectives.

Many water quality models currently exist, such as QUALs, CE-QUAL-W2, MIKE 11, SWAT, WASP, HSPF, ELCOM-CAEDYM, and EFDC [1], [2]. Most of these models involve the use of numerical methods for solving partial differential equations describing mass conservation and hydrodynamic motions for computing unsteady flow, discharge, and water level in streams. In a few special cases, it is possible to solve the equations analytically.

Of the existing models, QUAL2E and QUAL2K have been widely used in water quality prediction and pollution management. The US Environmental Protection Agency released a series of QUAL models such as QUAL2E, QUAL2EUNCAS, QUAL2K, and QUAL2Kw. These models allow for the simulation of up to 15 parameters associated with water quality, in any combination chosen by the user (DO, BOD, temperature, algae as chlorophyll a, organic nitrogen as $\mathrm{N}$, ammonia as $\mathrm{N}$, nitrite as $\mathrm{N}$, nitrate as $\mathrm{N}$, organic phosphorus as $\mathrm{P}$, dissolved phosphorus as $\mathrm{P}$, coliform bacteria, one arbitrary nonconservative constituent solute, and three conservative constituent solutes).

Even for one-dimensional, steady-state models, both

Manuscript received December 18, 2015; revised April 21, 2016. This work was supported by Graduate School of Water Resources, Sungkyunkwan University.

The authors are with Sungkyunkwan University, Suwon, Korea (e-mail: yyjyj@skku.edu,donghee4x@skku.edu, jllee@skku.edu). advective and dispersive modes of transport are considered in mass balance, which can be expressed as

$$
V=\frac{\partial c}{\partial t}=\frac{\partial\left(\frac{A_{c} E \partial c}{\partial x}\right)}{\partial x} d x-\frac{\partial\left(\left(A_{c} U\right)\right)}{\partial x} d x+V \frac{d c}{d t}+s
$$

where $V$ is the volume, $c$ is the concentration of the constituent, $A_{c}$ is the element's cross-sectional area, $E$ is the longitudinal dispersion coefficient, $x$ is the distance (in the direction of flow from the load point), $U$ is the average velocity, and $s$ is the external sources (positive) or sinks (negative) of the constituent [1].

In this study, we present a water quality model, WAQUMURIN for the purpose of urban wastewater management. It was developed using a MATLAB GUI and designed to identify how urban pollution affects water quality in a semi-steady state and to predict pollution transport and fate in complicated urban stream systems.

With a goal of use in practical management, the present model includes BOD and DO dynamics; nutrients and eutrophication; and bacterial, organic chemical, and heavy metal contamination. The model was run for predicted BOD levels in the Han River basin of Seoul, Korea, as a case study and the results were compared with measured data.

\section{MODEL DESCRIPTION}

The model was designed to have two functions for managing water quality in complicated urban river networks: one was to estimate the water quality and the other was to manage the maximum amount of waste load, such as from combined sewer overflows. The model begins on the main menu page, as shown in Fig. 1, where the mesh formulation of cell size, cell property, flow input, flow confirmation, waste load, and water quality calculations are determined.

\section{A. Mesh Cell Formulation}

The model uses an $n \times n$ mesh cell system in which cells are linked by a combination of rivers, lakes, and estuaries from upstream to downstream. Unlike the finite difference approach, a cell is not divided by a uniform length size but rather is assigned a length size based on one or a combination of the following: uniform hydraulic characteristics, location of point sources, zone of lateral nonpoint sources, monitoring position, or zone of interest. The cell properties are defined in advance for the simulation.

Fig. 2 is an example of a long lake in a stream with the converging lake upstream and diverging lake downstream. The lake is divided into three yellow colored cells in this 
example. River, lake, estuary, and land cells are cyan, yellow, green, and brown colored, respectively.

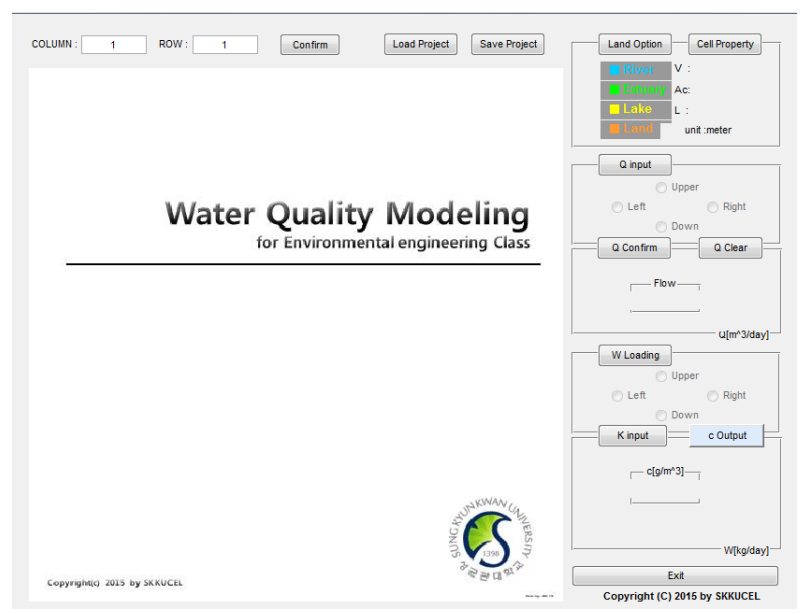

Fig. 1. Model program layout.

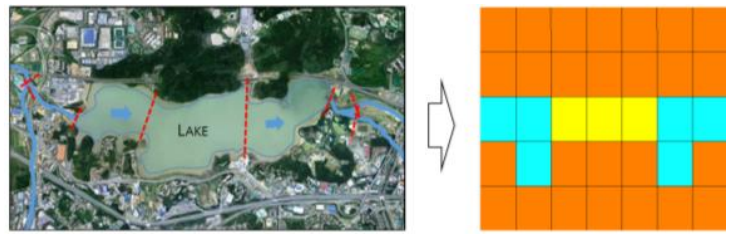

Fig. 2. Mass balance of unit mesh for a lake.

Once the grid structure is formulated, a preprocessing of each cell is required because water quality or waste loading can be obtained based on flow information and the volume of the lake cell or length and cross-sectional area of the river cell. The pre-process is shown in detail in Fig. 3.

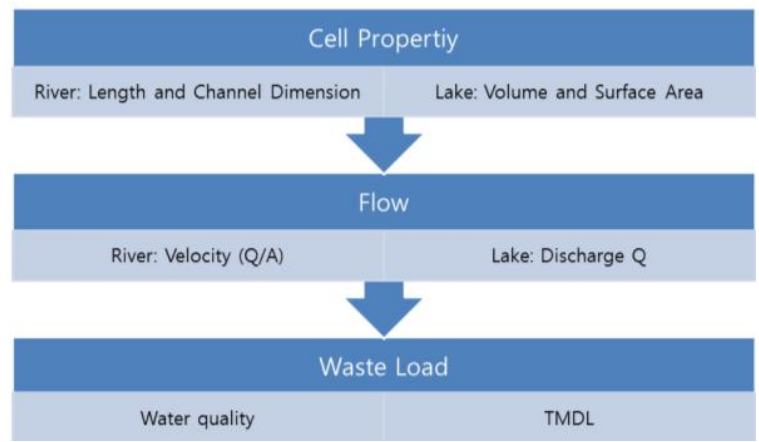

Fig. 3. Model pre-process.

\section{B. Flow Input and Confirmation}

Water quality is normally determined according to flow conditions even though the same waste load is given. The present model was operated under the assumption of a steady state, thus uniform discharge was assigned to each mesh from the most upstream cell. However, in a cell where rivers converge, the upstream discharge of each branch was used to determine the downstream flow after convergence. Similarly, in a cell where a river diverges, a division ratio was used. Both of these scenarios are informed by a pop-up window as shown in Fig. 4. The flow confirmation was done by systematically moving downstream cell by cell from the most upstream cell as shown in Fig. 5.

\section{Water Quality Estimation in Lake}

Using the assumptions for a well-mixed reactor, the concentration in a lake cell was estimated as

$$
C_{\text {out }}=\frac{\left(C_{\text {in }} Q+W_{p}+W_{N}\right)}{Q+k V}
$$

where $C_{\text {in }}$ is the concentration at the lake entrance, $C_{\text {out }}$ is the concentration at the lake outlet, $W_{p}$ and $W_{N}$ are the waste loads of point and nonpoint sources respectively, $Q$ is the flow discharge, $k$ is the reaction factor, and $V$ is the lake volume. The theoretical locations of, $C_{i n}, C_{o u t}, W_{p}, W_{N}$, and $V$ are shown in Fig. 6.

\section{Water Quality Estimation for a River Point Source}

Factories and sewage treatment plants are two common types of point source.

$$
C_{\text {out }}=C_{\text {in }} \exp \left(-\frac{k L}{u}\right)
$$

where $C_{\text {in }}$ is the concentration at the upstream reach end, $C_{\text {out }}$ is the concentration at the downstream reach end, $L$ is the length of the unit reach, $u$ is the mean velocity, and $k$ is the reaction factor.

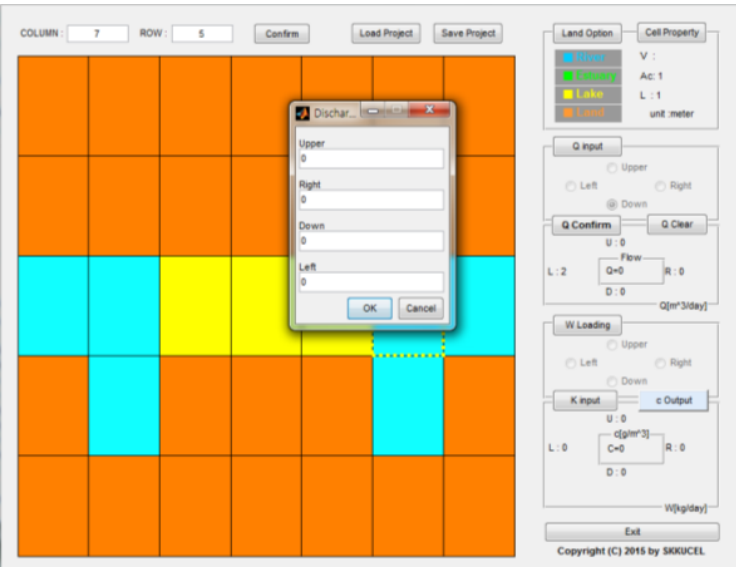

Fig. 4. Pop-up window showing the flow process.
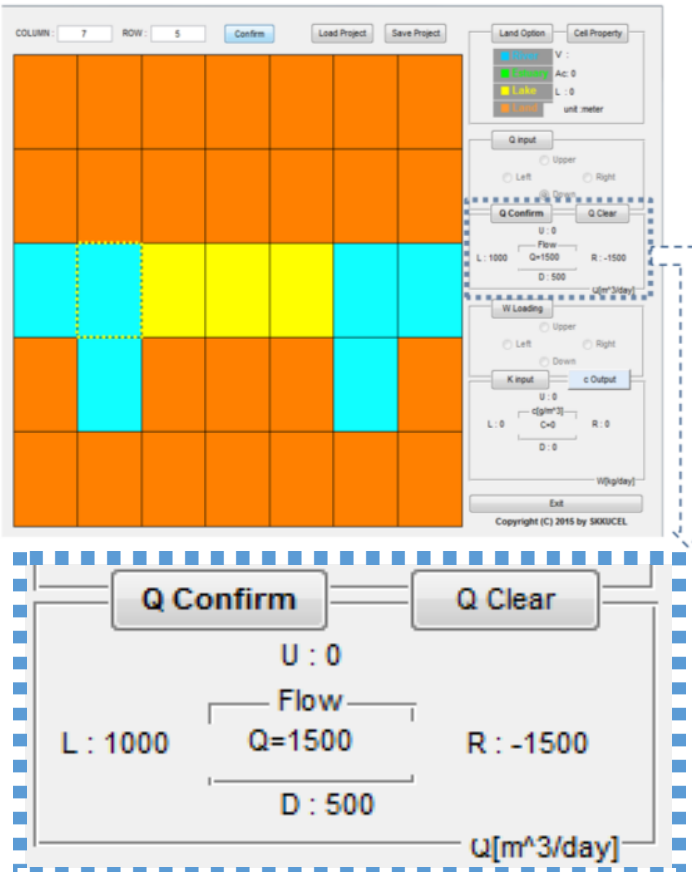

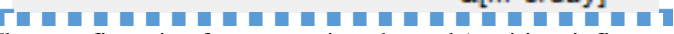

Fig. 5. Flow confirmation for converging channel (positive: inflow; negative: outflow). 

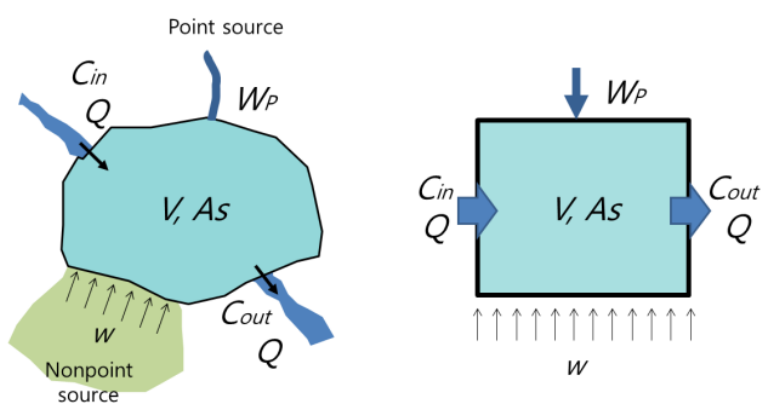

Fig. 6. Mass balance of unit mesh for a lake.

\section{E. Water Quality Estimation for a River Nonpoint Source}

Runoff containing pollutants from sources, such as road and atmospheric inputs, from urban and suburban areas as well as agricultural operations is a major nonpoint source. Surfaces paved with asphalt or concrete make it easier for runoff flow to pick up, absorb, and carry pollutants into a stream as a form of nonpoint source pollution. This untreated, polluted water then runs directly into the sewer system and eventually can lead to massive fish kills due to severely decreased levels of oxygen in the main stream. In the present model, the nonpoint source in a cell was approximately treated by the cascade method as follows.

$$
C_{\text {out }}=\frac{C_{\text {in }}}{(1+k l / u)^{n-1}}+(n-1) \frac{W l / Q}{(1+k l / u)^{2}}
$$

where $W$ is the lateral waste loading measured per unit length, $l$ is the divided unit length of cascade, and $n$ is the number of cascade divisions as shown in Fig. 7.

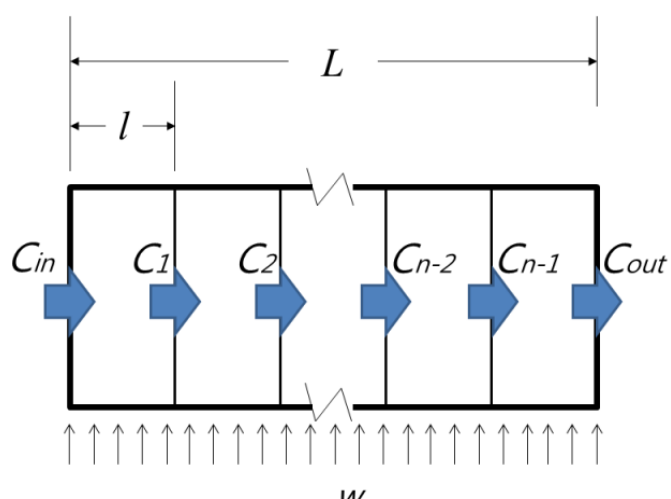

Fig. 7. Cascade approximation for lateral pollutants loaded to a unit reach.

\section{MODEL APPLICATION}

\section{A. Study Area Description}

The model was applied to the Han River basin in Seoul, Korea. The study area was bisected roughly into northern and southern halves by the Han River with a radius of approximately $15 \mathrm{~km}$ as shown in Fig. 8. The Han River is the fourth longest river in Korea and believed to influence economic growth; an effect deemed the "Miracle on the Han River."

The model is applied to Han River basin passing through Seoul, Korea. The study area is roughly bisected into northern and southern halves by Han River with radius of approximately $15 \mathrm{~km}$ as shown in Fig. 8 . The Han River is the longest river in Korea and believed to affect the economical growth as called the Miracle on the Han River.

The climate of this area is continental, meaning cold, humid, and having obvious seasonal variation. Annual precipitation, mainly occurring as summer rainfall, is approximately 1,450 $\mathrm{mm}$, and the yearly temperature averages about $12.5{ }^{\circ} \mathrm{C}$. Approximately $10,117,909$ people live in an area of 605.21 $\mathrm{km}^{2}$ as of October 31,2014 , creating a population density of about 17,000 people $/ \mathrm{km}^{2}$. Plottage and roads account for $42.1 \%$ and $12.5 \%$, respectively, of the land area.

Two national streams, the Jungnang and Anyang, enter the Han River as it passes through Seoul. The Han River also has four regional branches from the southern Seoul basin and three regional branches from the northern Seoul basin.

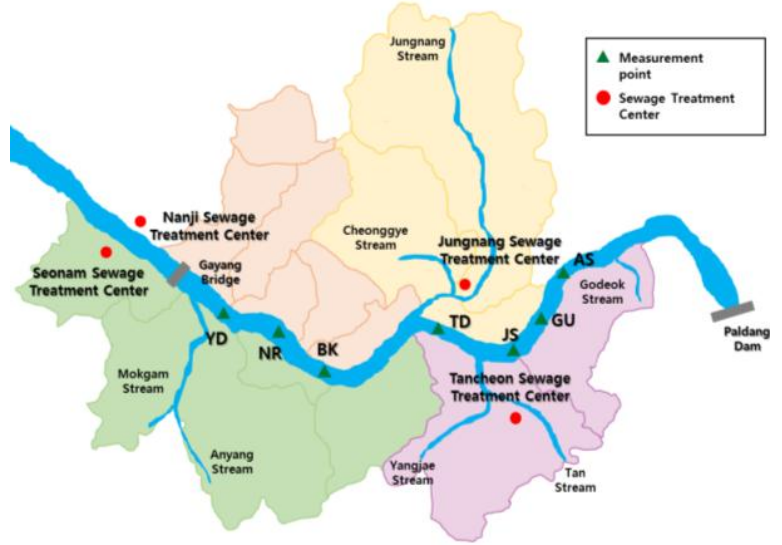

Fig. 8. Stream network of Han River in Seoul, Korea.

The Han River basin serves as an excellent natural laboratory for wastewater management studies. It was incorporated into a $30 \times 30$ mesh system as shown in Fig. 9 . The Han River has 13 river tributaries, but no lakes, in its Seoul metropolitan basin.

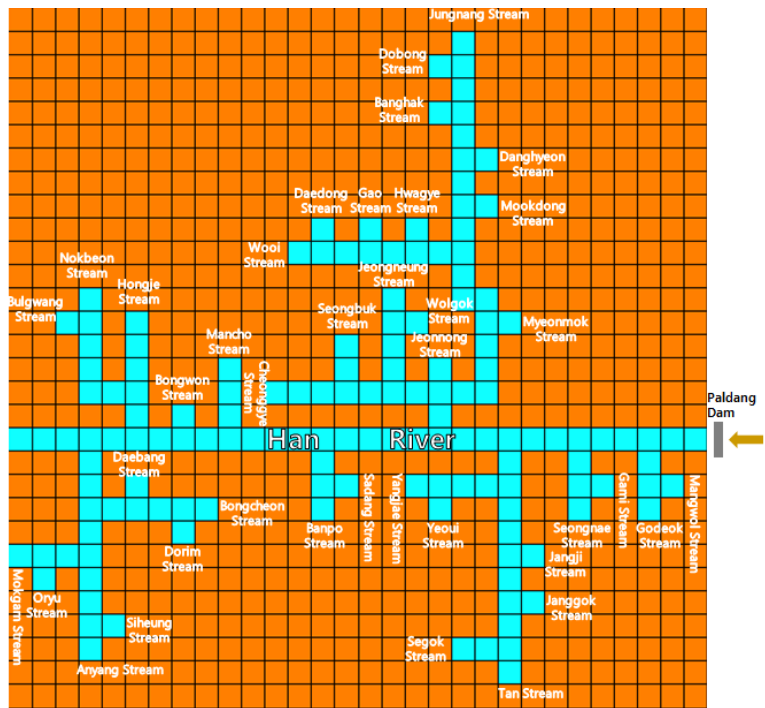

Fig. 9. Mesh system of WAQUMURIN applied to the Han River network of the Seoul metropolitan basin.

\section{B. Flow Condition}

The $Q_{355}$ flow conditions for main streams entering the Han River of the Seoul metropolitan basin are shown in Fig. 10. Flows from WWTPs are not included. A flow of 11,404,800 $\mathrm{m}^{3} /$ day enters from Paldang Dam (the most upstream cell of 
the main Han River) and a flow of $11,733,461 \mathrm{~m}^{3} /$ day outflows to the Gayang Bridge (the most downstream cell). Therefore, a flow of $328,529 \mathrm{~m}^{3} /$ day is added from the Seoul basin to the Han River.

\section{Waste Load Input}

The long-term average concentration of BOD has shown a consistent decreasing trend for 37 years. However, BOD shows an increasing trend along the main stream of the Han River as it flows downstream, whereas the BOD influx from Paldang Dam has maintained a decreasing trend because the nonbiodegradable materials in the Paldang Dam area are controlled [3]. BOD concentration from the Paldang Dam was $1.2 \mathrm{mg} / \mathrm{L}$ in 2012 [4].

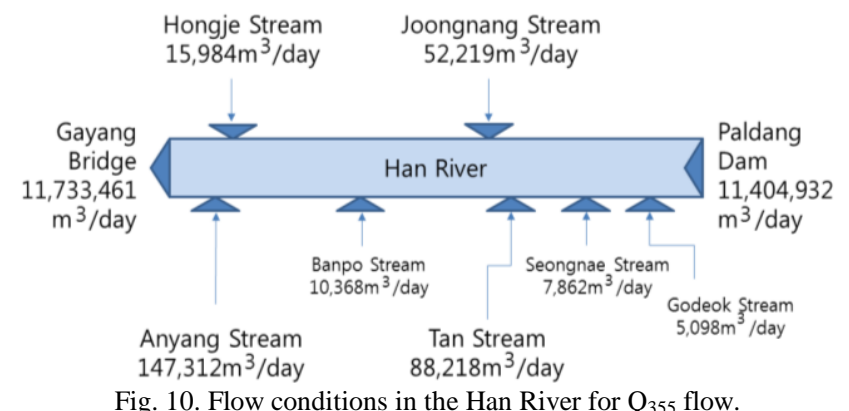

Pollution load is estimated in three steps: generation, discharge, and inflow into the stream, and each step is accomplished using numerous data sources, such as population census data, land use status, quantity and quality data for industrial and livestock wastewater, wastewater discharge inventory for each industry, ratio of collection to treatment, and status of wastewater treatment systems.

The generated BOD load was estimated as 764,642 kg/day, with each person generating approximately $76 \mathrm{~g} /$ person/day in 2013. The discharged BOD load was estimated as $84,880.32 \mathrm{~kg} / \mathrm{day}$, and point and nonpoint source loads in the Seoul basin were estimated to be $40,365.59 \mathrm{~kg} / \mathrm{day}$ and $44,514.73 \mathrm{~kg} /$ day, respectively, in 2013 . Seoul uses mainly combined sewer systems $(96.38 \%)$, but separated sewer systems $(3.60 \%)$ have also been adopted. In addition, a small amount of wastewater remains untreated $(0.02 \%)$. The distribution of pollution load in Seoul is listed in Table I.

TABLE I: POllution LOAD (KG/DAY) DistribUtion IN SEOUl [5]

\begin{tabular}{crrr}
\hline \hline \multirow{2}{*}{ Pattern } & Generated & \multicolumn{2}{c}{ Discharged Load } \\
\cline { 3 - 4 } & Load & Point Source & Nonpoint Source \\
\hline Household & 689,252 & 23,445 & 16,400 \\
Livestock & 196 & 0 & 18 \\
Industry & 46,003 & 458 & 16 \\
Land & 29,168 & 16,463 & 28,081 \\
Landfill & 24 & 0 & 1 \\
Total BOD load & 764,643 & 40,366 & 44,515 \\
\hline \hline
\end{tabular}

Current wastewater facilities in Seoul have a total daily capacity of 5.81 million tons. Sewage treatment areas have been divided into four based on a facility's location as shown in Fig. 8. The Jungnang and Nanji WWTPs are located in the east and west sides of the northern zone of the Han River respectively. The Tancheon and Seonam WWTPs are located in the east and west sides of the southern zone respectively. In
2012, the Joongnang WWTP discharged a BOD load of $1,344,338 \mathrm{~m}^{3} /$ day with $7.2 \mathrm{mg} / \mathrm{L}$ of BOD after treatment, the Nanji WWTP discharged a BOD load of $620,987 \mathrm{~m}^{3} /$ day with a BOD concentration of $6.8 \mathrm{mg} / \mathrm{L}$, the Tan WWTP released a BOD load of 793,618 $\mathrm{m}^{3} /$ day with a BOD concentration of $4.3 \mathrm{mg} / \mathrm{L}$, and the Seonam WWTP released a BOD load of 1,661,500 $\mathrm{m}^{3} /$ day with a BOD concentration of $7.1 \mathrm{mg} / \mathrm{L}$. The Nanji and Seonam WWTPs are located downstream of the Gayang Bridge as shown in Fig. 8. Fig. 11 shows the BOD load to the Han River in 2012 [4].

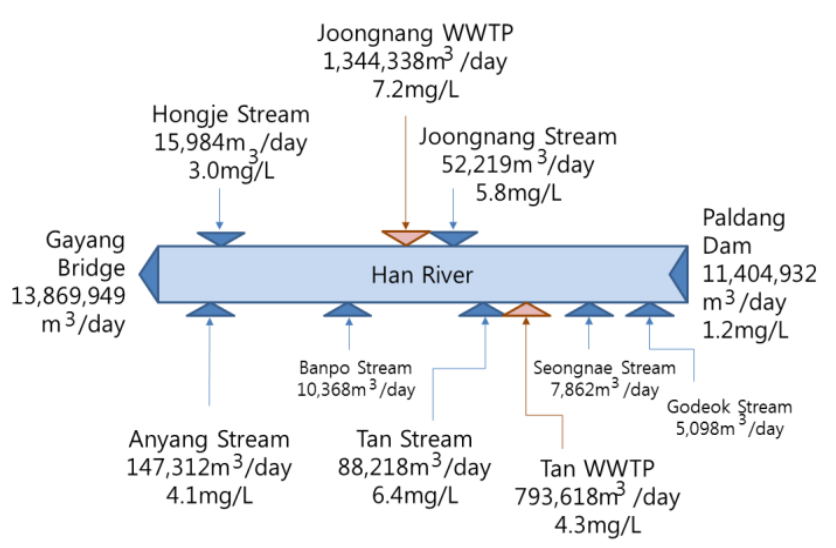

Fig. 11. BOD load to Han River.

\section{Comparison with BOD Concentrations}

The BOD concentrations were monitored at eight points along the mainstream Han River as listed in Table II and shown in Fig. 8. The upstream zone of the Han River was considered Grade 1 (the best water quality) for BOD concentration $(<2 \mathrm{mg} / \mathrm{L})$ as Paldang Dam and AS had 1.2 $\mathrm{mg} / \mathrm{L}$, JS had $1.5 \mathrm{mg} / \mathrm{L}$, GU had $1.7 \mathrm{mg} / \mathrm{L}$, and TD had 1.8 $\mathrm{mg} / \mathrm{L}$. The middle zone was considered Grade 2 for BOD concentration ( $<3 \mathrm{mg} / \mathrm{L})$ as $\mathrm{BK}$ and $\mathrm{YD}$ had $2.6 \mathrm{mg} / \mathrm{L}$ and 2.7 $\mathrm{mg} / \mathrm{L}$, respectively. The downstream zone was considered Grade 3 (average water quality) for BOD concentration $(<5$ $\mathrm{mg} / \mathrm{L}$ ) as GY had $3.1 \mathrm{mg} / \mathrm{L}$, NR had $3.2 \mathrm{mg} / \mathrm{L}$, and Haengju had $4.0 \mathrm{mg} / \mathrm{L}$. Table II shows the model results obtained from the flows and the BOD loading conditions of streams from Fig. 11 compared with measured BOD data. The calculated values from the model underestimated the measured BOD values in the downstream zone. This may be due to BOD loads from the Nanji and Seonam WTTPs diffusing upstream through the Han River.

TABLE II: COMPARISON BETWEEN MEASURED (2012) AND CALCULATED CONCENTRATIONS OF BOD

\begin{tabular}{lccc}
\hline \hline Locations & $\begin{array}{r}\text { Position } \\
\text { Symbol }\end{array}$ & $\begin{array}{c}\text { Measured Data } \\
(\mathrm{mg} / \mathrm{L})\end{array}$ & $\begin{array}{c}\text { Model Results } \\
(\mathrm{mg} / \mathrm{L})\end{array}$ \\
\hline Amsa & AS & 1.2 & 1.2 \\
Guui & GU & 1.7 & 1.4 \\
Jamsil & JS & 1.5 & 1.4 \\
Ttukdo & TD & 1.8 & 1.7 \\
Bokwang & BK & 2.6 & 2.2 \\
Noryangjin & NR & 3.2 & 2.5 \\
Yeungdeungpo & YD & 2.7 & 2.6 \\
Gayang & GY & 3.1 & 2.6 \\
\hline \hline
\end{tabular}


Water quality of the Han River has been greatly improved by treating pollutant loads to the river. However, there are still some difficulties in getting the effluent water to meet water quality standards when the rainfall seasonally exceeds the capacity of the sewer system. This is because the combined sewer system occupies $96 \%$ of the total sewer system of Seoul, and therefore pollutants are occasionally discharged directly into the Han River and its tributaries without any treatment when the sewer system is inundated with stormwater [6].

The seasonal variation of BOD in the Han River is as follows: spring>winter>summer and fall, although the amount of water discharged at Paldang Dam is systematically controlled. For integrated management purposes, the studied model easily and quickly simulates urban river networks using a GUI interface and is helpful for rapid understanding of water quality conditions.

\section{CONCLUSION}

This study presents a water quality model for urban stream networks. The model predicts contaminant concentration in urban stream networks, which are subdivided into unit reach meshes, thus accomplishing mass balance in each cell for nonconservative contaminants loaded from point and nonpoint sources on land. The model was developed by a GUI to provide a practical use for management purposes. To test the performance of the model, it was applied to the Seoul basin of the Han River network, which has eight stream branches.

\section{ACKNOWLEDGEMENT}

This work was financially supported by Graduate School of Water Resources, Sungkyunkwan University.

\section{REFERENCES}

[1] G. A. O. Liangliang and L. I. Daoliang, "A review of hydrological / water-quality," Frontiers of Agricultural Science and Engineering, vol. 1, no. 4, pp. 267-276, December 2014
[2] R. Paliwal, P. Sharma, and A. Kansal, "Water quality modelling of the river Yamuna (India) using QUAL2E-UNCAS," Journal of Environmental Management, vol. 83, no. 2, pp. 131-144, April 2007.

[3] H.-S. Cho et al., "A study on long-term variations of BOD and COD as indicators of organic matter pollution in the Han River," Korean J. Limnol, vol. 45, no. 4, pp. 474-481, 2012.

[4] Seoul Metropolitan Government (S MG), "Seoul water quality and aqua-ecological system conservation plan (2014-2018)," 2014.

[5] Seoul Metropolitan Government (S MG), "Seoul water pollution total management plan; 2013 Completion assessment," 2015.

[6] K. S. Kim, Y. R. Kim, and S. H. Hwang, "Characteristics of pollutants discharged into rivers/streams \& plan to reduce CSOs in urban area when raining," Japan-Korea Special Workshop on Impact Assessment and Control of Combined Sewer Overflow Associated Event of the 4th IWA-ASPIRE Conference \& Exhibition, 2011.

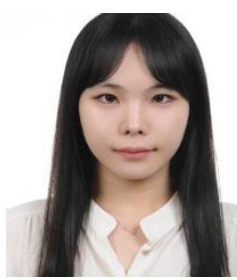

Yoon Jeong Yeon was born in Seoul, Korea, 1990. She received her bachelor degree in environmental science from Hankook University of Foreign Studies, Korea, in 2014. She is a now graduate student of master degree enrolled in the Department of Water Resources of Sungkyunkwan University, Korea. Her main research fields are the water quality modeling of practical use and the correlation analysis of bacterial communities measured on beach.

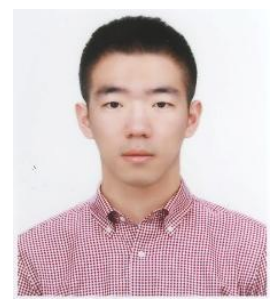

Dong Hee Kim was born on Busan, Korea, 1994. He received his bachelor degree in civil engineering from Sungkyunkwan University, Korea, 2015. He is a now graduate student of master degree enrolled in Interdisciplinary Program in Crisis, Disaster and Risk Management of Sungkyunkwan University, Korea. His current research fields are the numerical modeling in hydraulics and coastal engineering fields.

Jung Lyul Lee received his Ph.D degree from University of Florida in 1993. $\mathrm{He}$ is currently a professor in the Department of Water Resources and Interdisciplinary Program in Crisis, Disaster and Risk Management of Sungkyunkwan University, Korea. His current research fields are coastal engineering and management. 